University of Nebraska - Lincoln

DigitalCommons@University of Nebraska - Lincoln

USDA National Wildlife Research Center - Staff Publications
U.S. Department of Agriculture: Animal and Plant Health Inspection Service

January 2003

\title{
Prevalence and economic value of feral swine damage to native habitat in three Florida state parks
}

Richard M. Engeman

USDA-APHIS-Wildlife Services, s_r100@yahoo.com

Henry T. Smith

Florida Department of Environmental Protection, Florida Park Service

Stephanie A. Shwiff

USDA/APHIS/WS National Wildlife Research Center, stephanie.a.shwiff@aphis.usda.gov

Bernice Constantin

USDA-APHIS-Wildlife Services

John Woolard

USDA-APHIS-Wildlife Services

See next page for additional authors

Follow this and additional works at: https://digitalcommons.unl.edu/icwdm_usdanwrc

Part of the Environmental Sciences Commons

Engeman, Richard M.; Smith, Henry T.; Shwiff, Stephanie A.; Constantin, Bernice; Woolard, John; Nelson, Mark; and Griffin, Daniel, "Prevalence and economic value of feral swine damage to native habitat in three Florida state parks" (2003). USDA National Wildlife Research Center - Staff Publications. 174.

https://digitalcommons.unl.edu/icwdm_usdanwrc/174

This Article is brought to you for free and open access by the U.S. Department of Agriculture: Animal and Plant Health Inspection Service at DigitalCommons@University of Nebraska - Lincoln. It has been accepted for inclusion in USDA National Wildlife Research Center - Staff Publications by an authorized administrator of DigitalCommons@University of Nebraska - Lincoln. 


\section{Authors}

Richard M. Engeman, Henry T. Smith, Stephanie A. Shwiff, Bernice Constantin, John Woolard, Mark Nelson, and Daniel Griffin 


\title{
Prevalence and economic value of feral swine damage to native habitat in three Florida state parks
}

\author{
RICHARD M. ENGEMAN ${ }^{1 *}$, HENRY T. SMITH ${ }^{2}$, STEPHANIE A. SHWIFF ${ }^{1}$, BERNICE \\ CONSTANTIN ${ }^{3}$, JOHN WOOLARD ${ }^{3}$, MARK NELSON $^{4}$ AND DANIEL GRIFFIN 5 \\ ${ }^{1}$ National Wildife Research Center, 4101 LaPorte Avenue, Fort Collins, CO 80521-2154, USA, ${ }^{2}$ Florida Department of Environmental \\ Protection, Florida Park Service, 13798 SE Federal Highway, Hobe Sound, FL 33455, USA, ${ }^{3}$ USDA/APHIS/WS, 2820 East University \\ Avenue, Gainesville, FL 32641, USA, ${ }^{4}$ Fonathan Dickinson State Park, 16450 SE Federal Highmay, Hobe Sound, FL 33455, USA and \\ ${ }^{5}$ Savannas Preserve State Park, 9551 Gumbo Limbo Lane, Fensen Beach, FL 34957, USA \\ Date submitted: 20 November 2002 Date accepted: 3 September 2003
}

\section{SUMMARY}

Feral swine (Sus scrofa) adversely affect the environment in many of the places where they have been introduced. Such is the case in Florida, but quantification and economic evaluation of the damage can provide objective bases for developing strategies to protect habitats. Swine damage to native wet pine-flatwoods at three state parks in Florida was monitored from winter 2002 to winter 2003. Economic valuations of damage were based on the US dollar amounts that wetland regulators have allowed permit applicants to spend in attempts to replace lost resources. The parks had different swine management histories and the damage patterns differed among them over time. Swine were intensively removed in 2000 from the first park, and it initially had the lowest habitat damage at $1.3 \%$, but as a result of natural and artificial population growth this damage rose to $5.4 \%$ by the conclusion of the study, and was valued at US\$ $19193-36498 \mathrm{ha}^{-1}$. The second park had no history of swine harvest and, over the monitoring period, damage escalated from $2.6 \%-6.4 \%$, with an associated value of US\$22 747-43257 ha ${ }^{-1}$. Swine were managed as game animals in the third park prior to its inclusion into the state parks system in 2000. Within this park, the proportion of area damaged decreased from $4.3 \%-1.5 \%$, valued at US\$5331-10 $138 \mathrm{ha}^{-1}$. This decrease may be a result of human activities associated with development of the park's infrastructure causing dispersal of animals conditioned to avoid humans by hunting. Damage was highly scattered in each park, as evidenced by a much higher proportion of sampling sites showing damage than the actual proportion of land area damaged. The dispersed nature of small amounts of damage would increase the effort required to recover habitat and thus damage value estimates are probably conservative. It was also impossible to incorporate values for such contingencies as swine impact to state and federally listed endangered plants in the parks, some of which are found nowhere else in the world.

\footnotetext{
* Correspondence: Dr Richard Engeman Tel: +1 9702666091 Fax: +19702666089 e-mail: richard.m.engeman@aphis.usda.gov
}

Keymords: alien species, benefit-costs, damage estimation, economic analysis, exotic species, feral hogs, feral pigs, invasive species

\section{INTRODUCTION}

Feral swine (Sus scrofa) can be a particularly destructive exotic species in the places where they have been introduced (USDA [US Department of Agriculture] 1999); they degrade habitat, and predate on and compete with native species (Choquenot et al. 1996; Taft 1999). In North America, DeSoto first introduced swine to Florida in 1539 (Towne \& Wentworth 1950) and, with additional introductions, the range of feral swine in the USA continues to expand (Gipson et al. 1997). The species possesses the highest reproductive potential of any large mammal in North America (Wood \& Barrett 1979; Hellgren 1999), and currently inhabits many areas in large numbers. Feral swine can also harbour a number of diseases transmissible to livestock or humans (see Becker et al. 1978; Conger et al. 1999; Romero \& Meade 1999; Taft 1999). In particular, the swine industry in the USA has nearly eradicated swine brucellosis and pseudorabies, but feral swine serve as a potential reservoir from which these diseases can be transmitted back to domestic stock (Taft 1999; Taylor 1999).

Funding to manage feral swine and restore habitat is finite and must be applied carefully to optimize the positive impact on the protected resources. Decisions on management actions towards destructive invasive species are based on economic constraints, but the metric for success of management actions is measured in resource improvement. Therefore, a means to estimate efficiently feral swine damage to habitats, and to apply a monetary value to the damage, would permit economic analyses to help guide and evaluate management actions. Here, in three Florida state parks with similar habitats, we estimate and monitor habitat damage by feral swine over a year, and apply economic valuations of that damage.

\section{METHODS}

Study areas

This study was conducted in the Jonathan Dickinson State Park, Atlantic Ridge Preserve State Park, and Savannas Preserve State Park, Florida, USA. Each park is centrally 
located along Florida's east coast and preserves similar, dwindling native habitats. All three parks share some characteristics. The habitat in each study area was a wet pine-flatwoods (Hartman 1978; Kautz 1987) dominated by South Florida slash pine (Pinus elliottii), with saw palmetto (Serenoa repens) as the primary understorey species. None of the parks presented barriers for swine movement in and out of their boundaries. Each park was wilderness surrounded by suburban and some urban encroachment. Therefore, even though the surrounding areas provided areas of habitat for feral swine, hunting or other public removal methods could not be applied for human health and safety reasons.

An 8300 ha area of Jonathan Dickinson State Park (JDSP) was studied. In recent years feral swine have been removed consistently from JDSP in order to eradicate an exotic species. The US Department of Agriculture/ Wildlife Services (USDA/WS) undertook an intensive supplemental effort to remove swine from JDSP in 2000.

The 1720 ha area surveyed in the Atlantic Ridge Preserve State Park (ARPSP) had a similar habitat to the area within JDSP. This park became part of the Florida State Park system in 2000 and hunting has been banned since then. Before 2000, it was used as a private hunting area, where, in addition to other species, feral swine were managed and hunted as game animals, rather than removed as an exotic pest species. Since its admission to the Florida park system, administrative attention to ARPSP has been devoted to the development required in order to open it to the public. Feral swine were first managed as a renewable resource, followed by a potential recovery period and human disturbance.

The 350 ha area within the Savannas Preserve State Park (SPSP) consisted of similar habitat to that in JDSP and ARPSP. Within the SPSP, feral swine were not managed as either exotic pests or game animals. SPSP also implemented a contract with the USDA/WS to carry out intensive swine removal beginning mid-winter 2003 (approximately the conclusion of our study).

\section{Sample design}

Sites for sampling damage were located using the low-use, single-lane dirt (primitive) roads that permeated each of the study areas. We also wanted the sample sites to be suitable for future swine population indexing procedures (Engeman et al. 2001) to monitor the impact of management actions on populations through the course of their implementation. Thus, we located sampling sites in association with dirt road locations devoid of vegetative growth in the road to ensure that, after tracking areas were installed, swine would not be able to visually distinguish the plots from the roadway. The saturation of the study areas with primitive roads, coupled with the random occurrences of potential sampling site locations devoid of vegetation, and our random selection among those locations, produced a random spatial pattern of sampling sites throughout the study areas. The distribution of sites was plotted and verified on maps, because the locations of all sites were recorded using a global positioning system (GPS) unit. Thirty-six sampling sites were located in ARPSP, 28 in JDSP, and 31 in SPSP. Swine populations were monitored and subject to consistent population control in JDSP (see Engeman et al. 2001), but no prior data existed for ARPSP and SPSP. Therefore, ARPSP and SPSP were sampled more heavily relative to their areas.

\section{Damage measurements}

Each sampling site location along the road system defined the positioning for two damage assessment plots. On one side of the road, a damage plot was established $1 \mathrm{~m}$ perpendicularly outward from the road edge. Each damage plot was a $5 \times$ $1 \mathrm{~m}^{2}$ rectangle, established using a $1 \times 1 \mathrm{~m}^{2}$ square constructed of PVC pipe, folded over four more times beyond its initial placement. Cryptically placed, sandcoloured, wooden stakes in diagonal corners defined the plot for future reference. The second damage plot defined at the same road location was constructed in the same manner on the opposite side of the road with its placement beginning $3 \mathrm{~m}$ in the opposite direction from the first plot, and leading away from the opposite damage plot. Damage was sampled in late winter 2002, spring 2002 and mid-winter 2003.

The $1 \times 1 \mathrm{~m}^{2}$ squares were used to provide accurate and repeatable measurements of the area damaged within the $5 \times$ $1 \mathrm{~m}^{2}$ plots to the nearest $5 \%$. String was placed in a ' + ' sign across the $1 \times 1 \mathrm{~m}^{2}$ square to divide the area into four equal quadrants. Thus, damage was measured over 20 of these $0.25 \mathrm{~m}^{2}$ quadrants for each of the $5 \times 1 \mathrm{~m}^{2}$ plots. Swine damage was defined as overturned ground during foraging (rooting) activity. Tracks verified the species responsible. Armadillos (Dasypus novemcinctus) were the only other species in the parks that could produce similar (very small) patches of damage, but they were easily distinguished from swine damage by examining tracks and whether the ground was overturned or dug by forefeet.

The areas within the state parks that were sampled for damage (described earlier) were derived from GIS maps of the parks. The percentage of those areas damaged by swine was calculated in two ways. First, the percentage of the plots containing damage provided a rough estimate. The mean area damaged among all sample sites (two damage plots per site) provided a more accurate and precise estimate of damage.

\section{Data analyses}

The area of damage at each sampling site followed a two-factor repeated measures design, with season as the repeated factor (Winer 1971). Park represented the fixed factor and season had three (repeated) levels (late winter 2002, spring 2002, mid-winter 2003). The data were analysed as a mixed linear model (see McLean et al. 1991; Wolfinger et al. 1991). The calculations were performed using SAS PROC MIXED, with a restricted maximum likelihood estimation procedure (REML; Littell et al. 1996). 


\section{Damage valuation}

Special habitats such as wetlands have limited market value, and if such habitat is selectively protected, the market value diminishes further (King 1998). The use of contingent valuation surveys for special habitats, analogous to those applied to endangered animals (Engeman et al. 2002, 2003), tend to be even more abstract appraisals of value (King 1998). Estimated costs for restoring habitat to pristine condition (replacement costs) frequently produce values well in excess of the public's willingness-to-pay, and therefore do not represent a realistic valuation. The most defensible, logical and applicable valuation for the damaged habitat characteristic of the three parks in which our study took place was to use expenditure data for permitted wetland mitigation projects in the USA. Such data represent an empirical demonstration of willingness-to-pay value. King (1998) presented the US dollar amounts per unit area spent in efforts to restore a spectrum of wetland habitat types. The numbers represent the US dollar amounts that environmental regulators, and to a degree elected governments, have allowed permit applicants to spend in attempts to replace lost wetland services and values (King 1998). We identified the dollar value for the appropriate wetland habitat category from each of the two studies in King (1998). For these two studies, the habitats from our study areas would be classified as freshwater forested or emergent forested, with respective 1997 empirical willingness-to-pay dollar values of US $\$ 306404 \mathrm{ha}^{-1}$ and US $\$ 582659 \mathrm{ha}^{-1}$ (King 1998). The 2002 values for each of these willingness-to-pay dollar amounts after adjusting for a 3\% annual rate of inflation (Zerbe \& Dively 1994) were US $\$ 355429 \mathrm{ha}^{-1}$ and US $\$ 675884 \mathrm{ha}^{-1}$, respectively. The cost-per-unit area of swine damage in each of the parks was calculated by multiplying the estimated proportion of area damaged by swine by the cost-per-unit area for habitat restoration.

\section{RESULTS}

\section{Damage estimates}

The amounts and values of swine damage in the three parks varied over time (Table 1), and were reflected in the park-by-time interaction $\left(F_{3158}=2.35, p=0.07\right)$. JDSP, where swine were targeted for intensive removal in 2000, had $1.3 \%$ of the area damaged in spring of 2002 , but by mid-winter 2003 this level had risen to $5.4 \%$ (Table 1). SPSP, which had no history of swine harvest, showed $2.6 \%$ damage in late winter 2002 but this value climbed steadily to $6.4 \%$ by mid-winter 2003 (Table 1). ARPSP, where swine had been managed as a game animal followed by a two-year period during which no swine were harvested and the construction of the park infrastructure was initiated, had $4.3 \%$ of the area damaged in late winter 2002. This level remained steady (no habitat recovery) through spring 2002, but dropped to $1.5 \%$ by mid-winter 2003 , indicating some habitat recovery (Table 1).

Damage was more widespread in each park than the average amounts of damage would indicate (Table 2). Over all parks and sampling periods, the prevalence of damage among the sample sites ranged from 1.9 to 15.5 times higher than the quantity of damage. The highly distributed nature of swine damage relative to the amount of damage is also reflected in the proportion of sampling sites with damage where damage was only recorded at one of the two $5 \times 1 \mathrm{~m}^{2}$ plots (Table 2). Over all parks and sampling periods, the number of sampling sites where both plots displayed damage ranged from $0-50 \%$, with $20 \%$ as the median. None of the sampling sites in ARPSP had damage recorded at both plots within one site during any sampling period.

\section{Damage valuations}

The restoration costs multiplied by the estimated proportion of the area in each park damaged by swine provided a range of two US\$ values for the average per hectare habitat damage inflicted by feral swine (Table 1). The respective values for freshwater forested and emergent forested swine damage per

Table 1 Estimated proportion of feral swine damage to wet pine-flatwoods over time in three Florida state parks (ARPSP = Atlantic Ridge Preserve State Park, JDSP = Jonathan Dickinson State Park, SPSP = Savannas Preserve State Park), and two economic valuations of that damage based on expenditure data for permitted wetland mitigation projects in the USA (King 1998) for 'freshwater forested' (FF) or 'emergent forested' (EF) habitat.

\begin{tabular}{|c|c|c|c|c|c|}
\hline Park & Season & Year & $\begin{array}{l}\text { Proportion } \\
\text { damaged }\end{array}$ & $\begin{array}{l}\text { FF value per } \\
\text { ha of damage } \\
\left(U S \$ h a^{-1}\right)\end{array}$ & $\begin{array}{l}\text { EF value per } \\
\text { ha of damage } \\
\left(U S \$ h a^{-1}\right)\end{array}$ \\
\hline \multirow[t]{3}{*}{ ARPSP } & Late winter & 2002 & 0.043 & 15283 & 29063 \\
\hline & Spring & 2002 & 0.043 & 15283 & 29063 \\
\hline & Mid-winter & 2003 & 0.015 & 5331 & 10138 \\
\hline \multirow[t]{2}{*}{ JDSP } & Spring & 2002 & 0.013 & 4621 & 8786 \\
\hline & Mid-winter & 2003 & 0.054 & 19193 & 36498 \\
\hline \multirow[t]{3}{*}{ SPSP } & Late winter & 2002 & 0.026 & 9241 & 17573 \\
\hline & Spring & 2002 & 0.047 & 16705 & 31767 \\
\hline & Mid-winter & 2003 & 0.064 & 22747 & 43257 \\
\hline
\end{tabular}


Table 2 Indicators of the highly distributed nature of feral swine damage in three Florida State parks (ARPSP = Atlantic Ridge Preserve State Park, JDSP = Jonathan Dickinson State Park, SPSP = Savannas Preserve State Park) are the contrast of the estimated proportion of land damaged with the proportion of sampling sites exhibiting damage, as well as the low proportion of sampling sites with damage where both plots received damage.

\begin{tabular}{llllll}
\hline \hline Park & Season & Year & $\begin{array}{l}\text { Proportion } \\
\text { damaged }\end{array}$ & $\begin{array}{l}\text { Proportion of } \\
\text { sites with } \\
\text { damage }\end{array}$ & $\begin{array}{l}\text { Proportion of } \\
\text { damaged } \\
\text { sites } \text { mith both } \\
\text { plots } \\
\text { damaged }\end{array}$ \\
\hline ARPSP & & & & 0 \\
& & & & 0.139 & 0 \\
JDSP & late winter & 2002 & 0.043 & 0.139 & 0.250 \\
& spring & 2002 & 0.043 & 0.028 & 0.143 \\
SPSP & mid-winter & 2003 & 0.015 & 0.143 & 0.333 \\
& spring & 2002 & 0.013 & 0.250 & 0.429 \\
& mid-winter & 2003 & 0.054 & 0.425 & 0.500 \\
\hline \hline
\end{tabular}

hectare increased from US\$4620 $\mathrm{ha}^{-1}$ and US\$ $8786 \mathrm{ha}^{-1}$ to US\$ $19193 \mathrm{ha}^{-1}$ and US\$36 $498 \mathrm{ha}^{-1}$ in JDSP, increased from US\$9241 ha $\mathrm{ha}^{-1}$ and US\$ $17573 \mathrm{ha}^{-1}$ to US\$22 $747 \mathrm{ha}^{-1}$ and US\$43257 ha $\mathrm{ha}^{-1}$ in SPSP, and decreased from US\$ $15283 \mathrm{ha}^{-1}$ and US\$29063 ha ${ }^{-1}$ to US\$ $5331 \mathrm{ha}^{-1}$ and US\$ $10138 \mathrm{ha}^{-1}$ in ARPSP.

\section{DISCUSSION}

In Florida, a premium is placed on sanctuaries for protection and preservation of habitats and species, especially as much of the natural habitat in Florida already has been lost to development. The three parks where our study took place are homes to myriad threatened and endangered plant and animal species, as well as their unique habitats (see Hartman 1978).

In estimating the monetary values of the swine damage to the habitat, we assumed standard costs for restoration. However, these parks contain a variety of threatened and endangered plant species (Gann et al. 2002), some of which are endemic. It is much more difficult to ascribe a monetary value to damage or loss of, such species (Engeman et al. 2003). In fact, values of endangered or threatened species have been deemed 'incalculable' in US Supreme Court case law (Tennessee Valley Authority vs Hill 1978). Thus, while we have provided monetary estimates of the value of swine damage in the parks, these values should be viewed as lower estimates for the value of potential damage. In addition, the magnitude of potential damage values is magnified further if the definition is broadened beyond habitat damage to include transmission of disease pathogens by swine to domestic livestock.

Clearly, when the value of swine damage per hectare in a park is multiplied by the total area sampled in that park, the total valuations for swine damage per park would run into millions of US dollars. That the park managed for swine removal initially had the lowest level of swine damage is intuitive. In 2000, an intensive swine removal effort was carried out at JDSP by contracting with USDA/WS, and resulted in both substantial reductions in the swine population and in an index of concomitant swine damage (Engeman et al. 2001). The additional cost to the park for that contract was approximately US\$ 5000 (adjusting for inflation, US\$5305 in 2002). This was only slightly greater than the average value for swine damage per hectare for the lowest observed damage level at JDSP when applying the lower of the two habitat valuation figures (Table 1). If the higher valuation figure was used, or if the mid-winter 2003 damage level was considered, then the contract cost was substantially less than the value of the average amount of swine damage to a single hectare. Even though swine continued to be removed by park personnel at every opportunity after conclusion of the intensive removal contract, damage increased as time elapsed after the completion of the intensive effort, with damage quadrupling from early 2002 to early 2003. The favourable conditions of a wet habitat and subtropical climate, coupled with the high reproductive potential of swine, would allow a rapid population growth within the time frame following that control effort (Wood \& Barrett 1979; Hellgren 1999). In addition, swine at a neighbouring property were poorly contained and probably artificially contributed to the population at JDSP (J. Woolard, personal observation 2002-2003).

The park with no swine management (SPSP) initially had a lower damage level than that where swine had been managed as a game species (ARPSP). However, the amount of damage steadily escalated in SPSP over the course of our study. Concurrent with the conclusion of our study, SPSP had the highest damage levels among the parks and had commenced a contract with USDA/WS for intensive swine removal. The cost of this contract was US\$7500, which was only a fraction of the value of the swine damage per unit area of habitat at the conclusion of our study, using either valuation figure.

At the time of our observations, two years had elapsed since the transfer of ARPSP to the state park system. Management of swine as a renewable hunting resource, 
followed by two years of no removals in the face of high reproductive rates, may have allowed substantial population growth. Moreover, the elimination of hunting pressure initially may have reduced the wariness of the swine in terms of foraging and occupied range, hence the highest initial damage levels among the three parks. However, hunted feral swine have demonstrated remarkable learning and conditioning capabilities, as exemplified by feral swine acting dead during aerial surveys for swine shot from helicopters (Saunders \& Bryant 1988). Thus, once the infrastructure development necessary to open the park to the public was implemented throughout the property (trail development, boundary marking and fences, etc.), animals previously conditioned to avoid humans through hunting might have been dispersed from this park, thus explaining the decreased damage levels at the conclusion of our study. At the time of our final damage assessment, an orange grove adjacent to the park was being harvested, with the dropped oranges providing a powerful attractant to draw feral swine away from the park, especially those that might have dispersed in that direction.

The use of the permanent damage plot locations provided a useful means to assess the changes in feral swine damage quantity and prevalence, while simultaneously providing information to describe the spatial distribution of their activity. Continued monitoring of these plots will provide data on the rates of habitat recovery after swine removal. We also established a realistic and defensible method for valuing swine damage using established empirical data for actual habitat restoration costs. The efficacy of swine management practices can then be evaluated on an economic basis, in addition to measures of population reduction (Engeman et al. 2001). Given the disparity between the costs for a control contract for an entire park and the average per unit area value of swine damage to land, we question how protection of such special and sensitive habitats from wholesale swine damage cannot be afforded.

\section{ACKNOWLEDGEMENTS}

K. Fagerstone and J.R. Mason provided insightful reviews of earlier drafts of this manuscript.

\section{References}

Becker, H.N., Belden, R.C., Brevault, T., Burridge, M.J., Frankenberger, W.B. \& Nicoletti, P. (1978) Brucellosis in feral swine in Florida. Journal of the American Veterinary Medical Association 173: 1181-1182.

Choquenot, D., McIlroy, J. \& Korn, T. (1996) Managing Vertebrate Pests: Feral Pigs. Canberra, ACT, Australia: Bureau of Resource Sciences, Australian Government Publishing Service: $163 \mathrm{pp}$.

Conger, T.H., Young, E. \& Heckmann, R.A. (1999) Brucella suis in feral swine. In: Proceedings of the 1999 National Feral Swine Symposium, pp. 98-107. Austin, TX, USA: Texas Animal Health Commission.
Engeman, R.M., Constantin, B., Nelson, M., Woolard, J. \& Bourassa, J. (2001) Monitoring changes in feral swine population and spatial distribution of activity. Environmental Conservation 28: 235-240.

Engeman, R.M., Shwiff, S.A., Constantin, B., Stahl, M. \& Smith, H.T. (2002) An economic analysis of predator removal approaches for protecting marine turtle nests at Hobe Sound National Wildlife Refuge. Ecological Economics 42: 469-478.

Engeman, R.M., Shwiff, S.A., Smith, H.T. \& Constantin, B. (2003) Monetary valuation methods for economic analysis of the benefit-costs of protecting rare wildlife species from predators. Integrated Pest Management Reviems (in press).

Gann, G.D., Bradley, K.A. \& Woodmansee, S.W. (2002) Rare Plants of South Florida: Their History, Conservation, and Restoration. Miami, FL, USA: Institute for Regional Conservation: $1056 \mathrm{pp}$.

Gipson, P.S., Hlavachick, B., Berger, T. \& Lee, C.D. (1997) Explanations for recent range expansions by wild hogs into midwestern states. Great Plains Wildlife Damage Control Workshop 13: $148-150$.

Hartman, B.J. (1978) Description of major terrestrial and wetland habitats of Florida. In: Rare and Endangered Biota of Florida. Volume 2: Birds, ed. H.W. Kale, pp. xvi-xix. Gainesville, FL, USA: University Presses of Florida.

Hellgren, E. (1999) Reproduction in feral swine. In: Proceedings of the 1999 National Feral Swine Symposium, pp. 67-68. Austin, TX, USA: Texas Animal Health Commission.

Kautz, R. (1987) Preliminary Cover Types for Landsat Inventory. Tallahassee, FL, USA: Florida Game and Freshwater Fish Commission, Office of Environmental Services, Nongame Wildlife Section.

King, D. (1998) The dollar value of wetlands: trap set, bait taken, don't swallow. National Wetlands Nemsletter July-August: $7-11$.

Littell, R.C., Milliken, G.A., Stroup, W.W. \& Wolfinger, R.D. (1996) SAS System for Mixed Models. Cary, NC, USA: SAS Institute.

McLean, R.A., Sanders, W.L. \& Stroup, W.W. (1991) A unified approach to mixed linear models. The American Statistician 45: 54-64.

Romero, C.H. \& Meade, P.N. (1999) Pseudorabies virus in feral swine: a research update. In: Proceedings of the 1999 National Feral Smine Symposium, pp. 73-74. Austin, TX, USA: Texas Animal Health Commission.

Saunders, G. \& Bryant, H. (1988) The evaluation of a feral pig eradication program during a simulated exotic disease outbreak. Australian Wildlife Research 15: 73-81.

Taft, A.C. (1999) Feral swine - national concerns. In: Proceedings of the 1999 National Feral Swine Symposium, pp. 25-26. Austin, TX, USA: Texas Animal Health Commission.

Taylor, R.B. (1999) Seasonal diets and food habits of feral swine. In: Proceedings of the 1999 National Feral Smine Symposium, pp. 58-66. Austin, TX, USA: Texas Animal Health Commission.

Tennessee Valley Authority vs Hill (1978) 437 US 153.

Towne, C.W. \& Wentworth, E.N. (1950) Pigs from Cave to Cornbelt. Norman, OK, USA: University of Oklahoma Press: $305 \mathrm{pp}$.

USDA (1999) Wild pigs hidden danger for farmers and hunters. Animal and Plant Health Inspection Services Information Bulletin 620, Washington, DC, USA: 7 pp. 
Winer, B.J. (1971) Statistical Principles in Experimental Design. New York, NY, USA: McGraw-Hill.

Wolfinger, R.D., Tobias, R.D. \& Sall, J. (1991) Mixed models: a future direction. In: Proceedings of the 16th SAS Users Group Conference, pp. 1380-1388 Cary, NC, USA: SAS Institute.
Wood, G.W. \& R.H. Barrett. (1979) Status of wild pigs in the United States. Wildlife Society Bulletin 7: 237-246.

Zerbe, R.O. \& Dively, D.D. (1994) Benefit-Cost Analysis: In Theory and Practice. New York, NY, USA: HarperCollins College Publishers. 